\title{
Circulating immune complexes and complement concentrations in patients with alcoholic liver disease
}

\author{
C GLUUD, H JANS
}

From the Department of Medicine, Division of Hepatology, the Blood Bank, and Department of Pathology, Hvidovre Hospital, University of Copenhagen, Denmark

SUMMARY A prospective evaluation of circulating immune complexes (CIC) and the activity of the complement system was undertaken in 53 alcoholic patients just before diagnostic liver biopsy. Circulating immune complexes were detected in $39 \%$ of patients with alcoholic steatosis $(\mathrm{n}=26)$, $58 \%$ of patients with alcoholic hepatitis $(n=12)$, and $60 \%$ of patients with alcoholic cirrhosis $(\mathrm{n}=15)$. No significant difference was found between the three group of patients. The activity of the complement system was within reference limits in the majority of patients and only slight differences were detected between the three groups. No significant differences were observed in liver biochemistry and complement concentrations in CIC-positive and CIC-negative patients. Detection of CIC in patients with alcoholic liver disease does not seem to be of any diagnostic value or play any pathogenic role. The high prevalence of CIC in these patients may be due to a depressing effect of ethanol on clearance of CIC or to increased immunological reactivity, or to both.

Alcoholic hepatitis and alcoholic cirrhosis have been associated with an increased prevalence of circulating immune complexes (CIC). ${ }^{1-3}$ Patients with alcoholic steatosis, however, have been reported CIC-negative in most studies. ${ }^{1-3}$

Circulating alcoholic hyaline and antibody to alcoholic hyalin have been demonstrated in patients with alcoholic hepatitis, but not in patients with alcoholic steatosis and cirrhosis. ${ }^{4}$ It has been suggested that alcoholic hyalin (or other immunogenic material), being released into circulation as a consequence of tissue destruction, led to the formation of immune complexes. ${ }^{2}$ Furthermore, severe liver-cell damage is supposed to cause a reduction in concentration of certain complement components. ${ }^{5}$

Detection of CIC and estimation of complement concentrations and activity may therefore have diagnostic and pathogenic implications in patients with alcoholic liver diseases. In order to examine the relation between presence of $\mathrm{CIC}$, the complement activity in serum and degree of liver damage, we studied chronic alcoholics just before diagnostic liver biopsy.

\section{Patients and methods}

\section{PATIENTS}

After informed consent 59 consecutive patients admitting a consumption of more than $50 \mathrm{~g}$ ethanol per day for at least two years and suspected of alcoholic liver disease were studied. Four patients with clinical signs of infection, one with rheumatoid arthritis and one with gout were excluded to avoid any possible effects of these diseases on the generation of CIC. The remaining 53 patients then formed the study group. Their age ranged from 25 to $66 \mathrm{yr}$ (median $50 \mathrm{yr}$ ), and all were men. Liver biopsy showed steatosis in 26, alcoholic hepatitis in 12 (with concomitant cirrhosis in 10), and alcoholic cirrhosis without hepatitis in 15 .

\section{LABORATORY INVESTIGATION}

Routine liver test included serum bilirubin, serum aspartate-aminotransferase (ASAT), serum alkaline phosphatase, serum albumin, plasma factor II + VII + X, plasma IgG, plasma IgA and plasma IgM.

CIC DETECTION AND COMPLEMENT ANALYSIS After fasting overnight serum and plasma were obtained by venepuncture just before diagnostic 
liver biopsy. The samples were stored at $-80^{\circ} \mathrm{C}$. Detection of CIC was performed by means of the complement consumption test (CCT) performed as a modification of the method described by Johnson et $a l^{6}{ }^{6}$ and in the continuous flow system previously described, ${ }^{7}$ using a $3.4 \%$ suspension of sheep red blood cells, optimally sensitised with rabbit haemolytic serum (Behringwerke AG). Heat-inactivated serum $\left(56^{\circ} \mathrm{C}, 60 \mathrm{~min}\right)$ was diluted $1 / 10$ and $1 / 18$ and incubated with one $\mathrm{CH} 90$ unit of guinea pig complement (Behringwerke $\mathrm{AG}$ ) for $30 \mathrm{~min}$ at $37^{\circ} \mathrm{C}$ just before analysis. The reduction in degree of haemolysis in the samples containing serum was expressed as a percentage of a control containing barbital-buffered saline instead of serum. The CCT was registered as positive if inhibition of haemolysis in patient serum dilutions were greater than the inhibition in corresponding serum dilutions obtained from 100 healthy volunteer blood donors. ${ }^{8}$ The total haemolytic activity of the complement system in serum (CH 50) was estimated in the same autoanalyser system. ${ }^{7}$ Quantification of the complement components $\mathrm{C1q}, \mathrm{C} 4, \mathrm{C} 3$ activator, $\mathrm{C} 5$ and $\mathrm{C} 9$ was performed by means of rocket immunoelectrophoresis, ${ }^{9}$ employing monospecific antisera (Behringwerke AG). The results were expressed as percentages of a pooled standard. Complement conversion products (split products) of $\mathrm{C} 4$ and $\mathrm{C} 3$ were detected in EDTA-plasma by means of crossed immunoelectrophoresis with monospecific antisera.

\section{STATISTICAL ANALYSIS}

Non-parametric Mann-Whitney test, Spearman rank correlation test, and Fischer's exact test were used in statistical analysis. The type I error was fixed at the $5 \%$ level.

\section{Results}

\section{LIVER BIOCHEMISTRY}

Patients with alcoholic hepatitis and patients with alcoholic cirrhosis had significantly $(p<0.05)$ higher concentrations of serum ASAT, serum alkaline phosphatase, and plasma immunoglobulins and significantly $(\mathrm{p}<0.05)$ lower concentrations of serum albumin than patients with alcoholic steatosis (Table 1). Patients with alcoholic hepatitis also had significantly $(p<0.05)$ higher concentrations of serum bilirubin than patients with steatosis. No significant differences were found in liver biochemistry of patients with alcoholic hepatitis and alcoholic cirrhosis.

\section{CIRCULATING IMMUNE COMPLEXES}

The prevalence of CIC was $39 \%, 58 \%$, and $60 \%$ in patients with alcoholic steatosis, hepatitis and
Table 1 Liver biochemistry in patients with histologically verified alcoholic steatosis $(n=26)$, alcoholic hepatitis $(n=12)$, and alcoholic cirrhosis $(n=15)$. Figures are medians and range

\begin{tabular}{|c|c|c|c|}
\hline $\begin{array}{l}\text { Variable } \\
\text { (reference limits) }\end{array}$ & $\begin{array}{l}\text { Alcoholic } \\
\text { steatosis }\end{array}$ & $\begin{array}{l}\text { Alcoholic } \\
\text { hepatitis }\end{array}$ & $\begin{array}{l}\text { Alcoholic } \\
\text { cirrhosis }\end{array}$ \\
\hline $\begin{array}{l}\text { S-bilirubin } \\
\quad(5-17 \mu \mathrm{mol} / \mathrm{l})\end{array}$ & $\begin{array}{l}9 \\
(6-52)\end{array}$ & $\begin{array}{l}18^{*} \\
(9-56)\end{array}$ & $\begin{array}{l}14 \\
(5-130)\end{array}$ \\
\hline $\begin{array}{l}\text { S-ASAT } \\
\quad(10-40 \mathrm{U} / \mathrm{l})\end{array}$ & $\begin{array}{l}39 \\
(12-226)\end{array}$ & $\begin{array}{l}85^{*} \\
(35-184)\end{array}$ & $\begin{array}{l}58 \\
(20-105)\end{array}$ \\
\hline $\begin{array}{l}\text { S-alkaline phosphatase } \\
(50-275 \mathrm{U} / 1)\end{array}$ & $\begin{array}{l}205 \\
(112-741)\end{array}$ & $\begin{array}{l}285^{*} \\
(150-860)\end{array}$ & $\begin{array}{l}315^{*} \\
(91-853)\end{array}$ \\
\hline $\begin{array}{l}\text { S-albumin } \\
\quad(540-800 \mu \mathrm{mol} / \mathrm{l})\end{array}$ & $\begin{array}{l}578 \\
(425-676)\end{array}$ & $\begin{array}{l}412^{*} \\
(309-516)\end{array}$ & $\begin{array}{l}521 * \\
(323-604)\end{array}$ \\
\hline $\begin{array}{c}\text { P-factor II }+ \text { VII }+X \\
(0 \cdot 7 \cdot 1 \cdot 3 \text { arbitrary } U)\end{array}$ & $\begin{array}{l}1 \cdot 2 \\
(0 \cdot 6-2 \cdot 0)\end{array}$ & $\begin{array}{l}0 \cdot 8^{*} \\
(0 \cdot 5-1 \cdot 3)\end{array}$ & $\begin{array}{l}0 \cdot 6^{*} \\
(0 \cdot 4-1 \cdot 2)\end{array}$ \\
\hline $\begin{array}{l}\text { P-IgG } \\
\qquad(80-185 \mathrm{KIU} / \mathrm{I})\end{array}$ & $\begin{array}{l}117 \\
(69-225)\end{array}$ & $\begin{array}{l}232^{*} \\
(160-278)\end{array}$ & $\begin{array}{l}184^{*} \\
(78-303)\end{array}$ \\
\hline $\begin{array}{l}\text { P-IgA } \\
\quad(30-210 \mathrm{KIU} / \mathrm{I})\end{array}$ & $\begin{array}{l}122 \\
(156-210)\end{array}$ & $\begin{array}{l}408^{*} \\
(191-561)\end{array}$ & $\begin{array}{l}262^{*} \\
(67-670)\end{array}$ \\
\hline $\begin{array}{l}\text { P-IgM } \\
\quad(25-179 \mathrm{KIU} / \mathrm{l})\end{array}$ & $\begin{array}{l}68 \\
(36-165)\end{array}$ & $\begin{array}{l}134 * \\
(59-205)\end{array}$ & $\begin{array}{l}115^{*} \\
(36-369)\end{array}$ \\
\hline
\end{tabular}

${ }^{*} \mathrm{p}<0.05$ when compared to patients with alcoholic steatosis. $\mathbf{S}=$ serum, $\mathbf{P}=$ plasma.

cirrhosis, respectively (Table 2). No significant difference could be found between the three groups, but when compared to controls all groups had a significantly $(p<0.05)$ raised prevalence of CIC. In the total group of patients $49 \%(95 \%$ confidence limits: $35-63 \%$ ) were CIC-positive.

Table 2 The prevalence of circulating immune complexes in controls and patients with alcoholic liver diseases

\begin{tabular}{lcccc}
\hline Group & $\begin{array}{l}\text { Number } \\
\text { tested }\end{array}$ & $\begin{array}{l}\text { Number } \\
\text { positive }\end{array}$ & $\begin{array}{l}\% \\
\text { positive }\end{array}$ & $\begin{array}{l}95 \% \text { confidence } \\
\text { limits (\%) }\end{array}$ \\
\hline Controls & 100 & 0 & 0 & $0-4$ \\
Alcoholic steatosis & 26 & $10^{*}$ & 39 & $20-59$ \\
Alcoholic hepatitis & 12 & $7^{*}$ & 58 & $28-85$ \\
Alcoholic cirrhosis & 15 & $9^{*}$ & 60 & $32-84$ \\
\hline
\end{tabular}

${ }^{*} \mathrm{p}<0.05$ when compared to controls.

\section{COMPLEMENT CONCENTRATIONS}

The Figure shows the complement concentrations in the three groups of patients with alcoholic liver disease. No significant differences were observed between the three groups, apart from patients with alcoholic hepatitis and cirrhosis having significantly $(p<0.05)$ lower concentrations of $\mathrm{C} 3$ activator than patients with alcoholic steatosis. Further, patients with alcoholic hepatitis had significantly $(p<0.05)$ higher levels of C5 than patients with steatosis. No significant changes were observed between patients with alcoholic hepatitis and alcoholic cirrhosis. All the median values of complement components were within the reference limits of normal controls. However, a number of patients in all groups had values either above or below reference limits. 


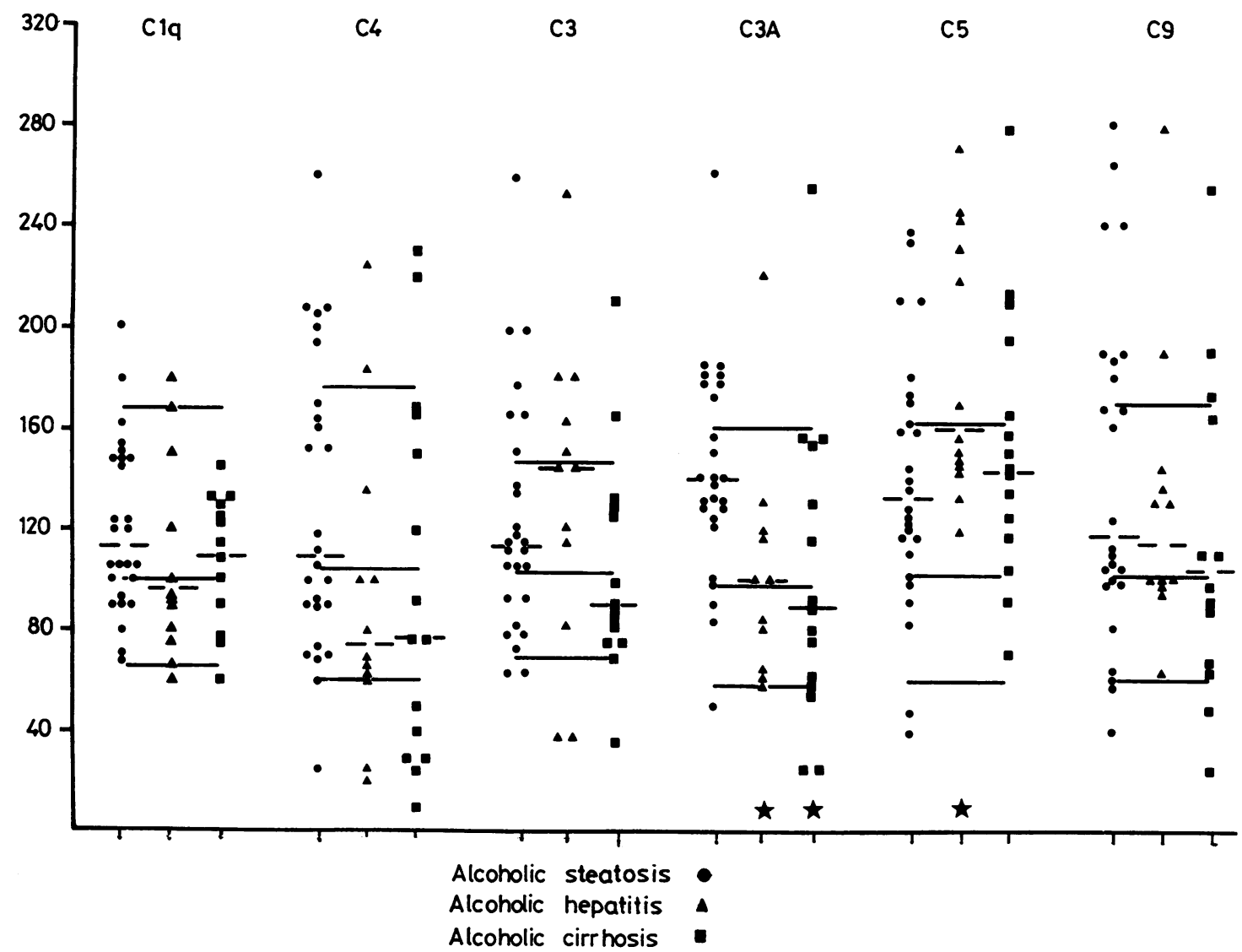

Complement concentrations ( $C 1 q, C 4, C 3, C 3$ activator $(C 3 A), C 5$, and $C 9)$ in patients with alcoholic steatosis ( $(\bullet)$, alcoholic hepatitis $(\Delta)$, and alcoholic cirrhosis $(\square)$. The horizontal non-broken lines represent median values and $95 \%$ limits of normal controls. Broken horizontal lines represent median values of patients. The stars represent $p<0.05$ when compared to patients with steatosis. Ordinate: percentage of standards.

Correlating $\mathrm{C} 3$ and $\mathrm{C} 9$ concentrations to serum albumin and plasma factor II + VII $+X$ values in the total groups of patients, showed that $\mathrm{C} 3$ correlated significantly with plasma factor II + VII $+\mathbf{X}$ $(r=+0.39, p<0.01)$. No other significant correlations were found.

In the total group of patients with alcoholic liver disease 16 patients had both $\mathrm{C4}$ and $\mathrm{C} 3$ split products $(30 \%, 95 \%$ confidence limits: $18-44 \%)$ while six patients had either $\mathbf{C 4}$ or $\mathbf{C} 3$ split products alone ( $11 \%, 95 \%$ confidence limits: $4-23 \%)$. No significant differences were found between the three groups of patients concerning $\mathrm{C4}$ and $\mathrm{C} 3$ split products, and occurrence of split products were not significantly correlated to low concentrations of $\mathbf{C 4}$ and $\mathrm{C} 3$.
LIVER BIOCHEMISTRY AND COMPLEMENT CONCENTRATIONS IN CIC-POSITIVE AND -NEGATIVE PATIENTS

Comparing CIC-positive patients $(n=26)$ with those without CIC $(n=27)$ showed no significant differences in liver biochemistry, including plasma immunoglobulin and serum albumin concentrations, and concentrations of complement components. Nine patients with detectable CIC had simultaneous activation of both $\mathrm{C} 4$ and $\mathrm{C} 3$, suggesting in vivo activation of the complement system via the classical pathway. However, seven patients without detectable CIC also had activation of both $\mathrm{C} 4$ and $\mathrm{C} 3$.

\section{Discussion}

The present study confirms and extends previous 
findings of a high prevalence of CIC in patients with alcoholic liver disease. All patients were examined just before diagnostic liver biopsy. The patients were referred to the department because of symptoms attributable to liver disease, and patients who exhibited symptoms of other diseases which could cause CIC were excluded from this study. A prevalence of CIC in $60 \%$ of patients with alcoholic cirrhosis are in agreement with earlier studies. Penner $e t a l^{2}$ found CIC in $50 \%$ of patients with alcoholic cirrhosis using the Raji-cell assay. In a recent study, Abrass et al ${ }^{10}$ found CIC in 63 and $73 \%$ of patients with alcoholic liver disease (mostly alcoholic hepatitis and cirrhosis) using solid-phase $\mathrm{C} 1 \mathrm{q}-$-binding assay and fluid-phase $\mathrm{C1}$ q-binding assay.

Only limited and conflicting data are available concerning the prevalence of CIC in patients with alcoholic steatosis. Sodomann $e a^{3} l^{3}$ and Penner $e t a l^{2}$ found no CIC-positive cases in patients with alcoholic steatosis using $\mathrm{Clq}$ deviation and precipitation methods and the Raji-cell assay. Thomas et al ${ }^{1}$ reached the same conclusion using Clq-binding to detect CIC, but in five patients with steatosis they found an increased level of anticomplementary activity. In this study the prevalence of CIC was $39 \%$ in patients with alcoholic steatosis which is significantly increased compared to controls. The reason for these discrepancies is not known, but earlier studies concerned only a limited number of subjects and, probably most importantly, different methods of detection of CIC have been employed. Different methods for detection of CIC is based on variqus biological properties of the complexes. Therefore, different techniques may show varying results. ${ }^{11}$ The complement consumption test has proved its ability to detect IgG aggregates of both intermediate size and sizes $>19 \mathrm{~S}$, whereas other techniques such as the $\mathrm{Clq}$ precipitation and the platelet aggregation test only detects large CIC ( $>19$ S). ${ }^{12}$ The complement consumption test can give rise to false positive results in patients with alcoholic liver disease due to aggregated globulin or the presence of activators of the complement system such as lipopolysaccharide. Aggregation of immunoglobulin may occur because of either low serum albumin or high plasma immunoglobulin. However, we found no significant difference in the concentration of these proteins between CIC-positive and -negative patients. Earlier studies have reported an increased prevalence of endotoxin, the lipopolysaccharide component of the cell wall of Gramnegative bacteria, in patients with cirrhosis. However, a recent study, in which inadvertent contamination of specimens by endotoxin was avoided, was not able to detect any endotoxin. ${ }^{13}$ It should also be stressed that the complement consumption test may give false-negative results as only complement-fixing immune complexes are detected.

The nature of the antigen or antigens involved in CIC in patients with alcoholic liver disease is not known. Several possibilities exist. Kanagasundaram et $a^{4}$ demonstrated circulating alcoholic hyalin and its antibody in patients with alcoholic hepatitis. This antigen-antibody system could not be detected in patients with alcoholic steatosis or alcoholic cirrhosis. In our study, the prevalence of CIC in patients with alcoholic hepatitis was not significantly different from the prevalence in patients with alcoholic steatosis or cirrhosis. Kehl et al ${ }^{14}$ were not able to confirm the findings of Kanagasundaram et al. ${ }^{4}$ Our findings do not seem to support the hypothesis that CIC in patients with alcoholic liver disease should be composed of alcoholic hyalin and antialcoholic hyalin as the prevalence of CIC was not increased in patients with alcoholic hepatitis. In accordance with this assumption is the fact that we could find no significant differences in liver biochemistry in CIC-positive and -negative patients. However, attempts should be made to identify the antigen(s) of CIC before this question can be settled.

Studies in patients with primary biliary cirrhosis have revealed a significant correlation between concentrations of $\mathrm{CIC}$ and titres of antimitochondrial antibodies. ${ }^{15} \mathrm{An}$ association between CIC and autoantibodies has also been described in patients with insulin-dependent diabetes mellitus and in normal controls. ${ }^{16}$ Patients with alcoholic cirrhosis have a high prevalence of autoantibodies, ${ }^{17-19}$ and it is suggested that autoantibodies are involved in at least some of the CIC found in patients with alcoholic liver disease.

In patients with liver disease a high prevalence of CIC could be due to increased formation, but may also be caused by a decreased clearance. The hepatic reticuloendothelial system is known to clear the circulation of immune complexes. ${ }^{20} \mathrm{~A}$ decreased hepatic clearance of antigen has been described in animals with experimental cirrhosis, ${ }^{21}$ but this would not explain the high prevalence of CIC in patients with steatosis. However, alcohol is known to depress the function of the reticuloendothelial system. ${ }^{22}$ Such an effect might explain the high prevalence of CIC found in alcoholics irrespective of degree of liver damage. Further, recent observations have clearly shown that parenchymal as well as nonparenchymal liver cells take up immune complexes. ${ }^{23}$ The uptake of CIC by parenchymal liver cells may also be depressed by alcohol.

Although many of our patients had complement concentrations either above or below normal reference limits, all median values fell within the normal range, and only minor differences were 
observed between the three groups of patients with alcoholic liver disease. Only a significant correlation was found between liver-cell damage, expressed by plasma factor II + VII $+\mathrm{X}$, and the concentration of $\mathrm{C} 3$. The occurrence of $\mathrm{C} 4$ and $\mathrm{C} 3$ split products, indicating in vivo activation of the complement system, did not explain the different concentrations of the complement components either. These findings are largely in accordance with earlier reports. ${ }^{5}$ 24-26 The level of complement proteins reflects the net synthesis and utilisation. Normal concentrations may therefore be seen in spite of significant activation of the complement system. Raised complement concentrations generally reflect an acute phase reaction, whereas depression reflects utilisation or decreased production. In patients with alcoholic liver disease all mechanisms may operate simultaneously so obscuring each other. This may explain why we are unable to demonstrate any uniform abnormality of either the classical or alternative activation pathway of the complement system.

In conclusion, CIC is found in about half of the patients with alcoholic liver disease. No relation between CIC and complement concentrations on one hand and complement concentrations and liver function on the other could be established. Therefore, determination of CIC does not seem to have diagnostic or pathogenetic value in patients with alcoholic liver disease. The increased prevalence of CIC in patients with alcoholic liver disease may be due to an inhibitory effect of alcohol on clearance of CIC or an increased immunological reactivity, or a combination of these effects.

\section{References}

${ }^{1}$ Thomas HC, De Villiers D, Potter B, et al. Immune complexes in acute and chronic liver disease. Clin Exp Immunol 1978;31:150-7.

${ }^{2}$ Penner E, Albini B, Milgrom F. Detection of circulating immune complexes in alcoholic liver disease. Clin Exp Immunol 1978;34:28-31.

${ }^{3}$ Sodomann C-P, Prokein K, Schmidt H, Martini GA. Zirkulierende Immunkomplexe bei Leberkrankungen. Z Gastroenterol 1978;16:501-11.

${ }^{4}$ Kanagasundaram N, Kakumu S, Chen T, Leevy CM. Alcoholic hyalin antigen (AHAg) and antibody (AHAb) in alcoholic hepatitis. Gastroenterology 1977;73:1368-73.

${ }^{5}$ Charlesworth JA, Lawrence S, Worsdall PA, Roy LP, Boughton CR. Acute hepatitis. Significance of changes in complement components. Clin Exp Immunol 1977; 28:496-501.

- Johnson AH, Mowbray JF, Porter KA. Detection of circulating immune complexes in pathological human sera. Lancet 1975 ; $: 762-5$

' Jans H, Jersild C, Taaning E, Dybkjaer E, Fog T, Heltberg A. The occurrence of immune complexes in patients with multiple sclerosis. In: Peeters $\mathrm{H}$, ed. Protides of the biological fluids 26. Oxford, New York: Pergamon Press, 1979:255-8.

8 Jans H. Circulating immune complexes in apparently healthy persons. Scand J Rheumatol 1980;9 suppl 33:39.
${ }^{9}$ Laurell C-B. Electroimmuno assay. Clin Lab Invest 1972; 29 suppl 124:21-37.

${ }^{10}$ Abrasse CK, Border WA, Hepner G. Non-specificity of circulating immune complexes in patients with acute and chronic liver disease. Clin Exp Immunol 1980; 40:292-8.

${ }^{11}$ Lambert PH, Dixon FJ, Zubler RH, et al. WHO collaborative study for the evaluation of eighteen methods for detecting immune complexes in serum. J Clin Lab Immunol 1979;1:1-15.

12 Nielsen H, Svehag SE. Detection and differentiation of immune complexes and IgG aggregates by a complement consumption assay. Acta Pathol Microbiol Scand 1976;84:261-9.

${ }^{13}$ Fulenwider JT, Sibley C, Stein SF, Evatt B, Nordlinger BM, Ivey GL. Endotoxemia of cirrhosis: An observation not substantiated. Gastroenterology 1980;78:1001-4.

${ }^{14}$ Kehl A, Schober A, Junge U, Winkler K. Solid-phase radioimmunoassay for detection of alcoholic hyalin antigen (AHAg) and antibody (anti-AH). Clin Exp Immunol 1981;43:215-21.

${ }^{15}$ Gupta RC, McDuffie FC, Dickson ER, Mehta S, Tan EM. The composition of the isolated soluble immune complexes in primary biliary cirrhosis (PBC). Gastroenterology 1978;75:967.

${ }^{16}$ Delexpesse G, Gransset PH, Sarfati M, Bubo-Rycquoy M, Debisschop M-J, Van Haelst L. Circulating immune complexes in old people and in diabetics: Correlation with autoantibodies. Clin Exp Immunol 1980;40:96-102.

${ }^{17}$ Bailey RJ, Krasner N, Eddleston ALWF, et al. Histocompatibility antigens, autoantibodies, and immunoglobulins in alcoholic liver disease. $\mathrm{Br}$ Med $J$ 1976;ii : 727-9.

${ }^{18}$ Krasner N, Davis M, Portmann B, Williams R. Changing pattern of alcoholic liver disease in Great Britain: Relation to sex and signs of autoimmunity. $\mathrm{Br}$ Med $J$ 1977;i:1497-1500.

${ }^{19}$ Gluud C, Tage-Jensen U, Bahnsen M, Dietrichson O, Svejgaard A. Autoantibodies, histocompatibility antigens and testosterone in males with alcoholic liver cirrhosis. Clin Exp Immunol 1981;44:31-7.

${ }^{20}$ Mannik M, Arned WP, Hall AP, Gilliland BC. Studies on antigen-antibody complexes: Elimination of soluble complexes from rabbit circulation. J Exp Med 1971; 133:713-39.

${ }^{21}$ Thomas HC, Singer CRJ, Tilney NL, Folch H, MacSween RNM. The immune response in cirrhotic rats. Antigen distribution, humoral immunity; cell-mediated immunity and splenic suppressor cell activity. Clin Exp Immunol 1976;26:574-82.

${ }^{22}$ Bjørneboe M, Prytz H. The mononuclear phagocytic functions of the liver. In: Ferguson A, MacSween RNM, eds. Immunological aspects of the liver and gastrointestinal tract. England: MTP Press, 1976:251-79.

${ }^{23}$ Hopf U, Schaefer HE, Hess G, Meyer zum Büschenfelde $\mathrm{KH}$. In vivo uptake of immune complexes by parenchymal and nonparenchymal liver cells in mice. Gastroenterology $1981 ; 80: 250-9$.

${ }^{24}$ Fox RA, Dudley FJ, Sherlock S. The serum concentration of the third component of complement $\beta_{1} \mathrm{c} / \beta_{1 \mathrm{~A}}$ in liver disease. Gut 1971;12:574-8.

${ }^{25}$ Teisberg $P$, Gjone E. Circulating conversion products of C3 in liver disease. Clin Exp Immunol 1973;14:509-14.

${ }^{26}$ Potter BJ, Elias E, Fayer PM, Jones EA. Profiles of serum complement in patients with hepatobiliary diseases. Digestion 1978;18:371-83.

Requests for reprints to: Dr Christian Gluud, Department of Medicine, Division of Hepatology, Hvidovre Hospital, DK-2650 Copenhagen, Denmark. 